\title{
A Critical Discourse Analysis for Advertisements in Instagram: Calvin Klein, Tommy Hilfiger and H\&M
}

\section{Ayşe Muhtaroğullari*}

English Language and Literature, Girne American University, University Drive, PO Box 5, 99428, Karmi Campus, Karaoğlanoğlu, Kyrenia/TRNC, Cyprus.

*Correspondence: aysemuhtarogullari@gau.edu.tr (Dr. Ayşe Muhtaroğulları, Assistant Professor, English Language and Literature, Girne American University, University Drive, PO Box 5, 99428, Karmi Campus, Karaoğlanoğlu, Kyrenia/ TRNC, Cyprus).

\begin{abstract}
Online Advertising has a significant influence in this modern century; because of this, famous companies effectively use online advertisements to introduce their products. Such as Calvin Klein, H\&M, and Tommy Hilfiger are some famous brand companies that use advertisements on social media for their marketing strategies. Those companies have influential followers on Instagram, and they reach many people around the world. Thus, they use online media to sell their products and deliver their cultural values to reach the target audiences. Namely, famous brand companies want to be part of the social changes. Because of this, they use visual and verbal discursive strategies for their advertisements to influence and change sociocultural values and stereotypes of people. In other words, advertisers use discursive language to persuade people to buy beliefs, values, and ideas besides commercial products. The visual and verbal language in online advertisements reveals the hidden meanings of stereotypes: body image, racism, and LGBT rights. Therefore, the qualitative analysis method uses to analyze the brands' advertisements. As a qualitative method, the writer applies the Critical Discourse Analysis to reveal the hidden meanings of Tommy Hilfiger, H\&M, Calvin Klein's Instagram Advertisement Photos. The analysis and interpretation reveal that advertisers use different people to show that those companies think about everyone and want to reach everyone. The body type is not essential, and consumers can find different sizes of clothes. In addition, advertisers promote different body images to shape society's ideas to purchase their products and show like celebrities, who are confident, happy with their colour, body size, sexual orientation, and ethnic minorities. Even visual and verbal languages show that differences are beautiful and make you forget/remove your boundaries to be free.
\end{abstract}

Keywords: Advertisements, Instagram, Photos, Critical discourse analysis, Tommy Hilfiger, and H\&M.

\section{INTRODUCTION:}

"Seeing comes before words. The child looks and recognizes before it can speak." (Berger, 2008); therefore, for social media and advertising, visual language has the same importance as verbal language. Even, sometimes visual language is more visible than words. Thus, online social media is powerful tool for people and branding companies to introduce their products and ideologies. Fashion advertising companies use online social media channels to "inUniversePG I www.universepg.com form and/or influence one or more people" (Jeremy Bullmore, 2017) and spread its messages to the target audience, such as Instagram, Facebook, and others. Primarily due to the pandemic, social media has an essential place for people and commercial companies. Famous brands start to use social media to share their products with consumers. For example, "If you have strong visual content to spare for ads, then Instagram will be your better choice. T" (Chen, 2020). The source shows that for the visual content, 
Instagram is the better choice for the marketing brands.

"Advertising is the most influential institution of socialization in modern society" (Jhally, 1990); because of this, Calvin Klein, H\&M, and Tommy Hilfiger are some famous brandcompanies that use advertisements on social media for their marketing strategies. Those companies use online media to reach the target audiences to sell their products and deliver their cultural values.

In other words, as Hackley (2005) mentions in his book, "Advertising has been cited as a force for cultural change of many kinds. Changes in the portrayals of brand consumption in advertisements both reflect and legitimize changes in the social world beyond advertising" (Chris, 2005). Namely, famous brand companies want to be part of the new changes, and because of this, they use visual and verbal discursive strategies for their advertisements to influence and change socio-cultural values and stereotypes of people.

\section{Literature review}

"A stereotype is a schema or a set of beliefs about a certain group of people" (Helgeson, 2012). For instance, a stereotype covers gender, racism, LGBT people, and body image or beauty. Moreover, in this popular culture age, advertising uses social media to create or change the stereotype of people. Put it differently, "Social media is shaping our concept of beauty. We are, for better or worse, constantly consuming images posted online. As a consequence, social media and body image - the way we perceive our own physical appearance have become inextricably linked" (2019). Because of this, especially young generations imitate famous models to shape their bodies. Accordingly, this is one of the reasons that brand companies use celebrities or known people and social media to introduce their products and reach people. For example, as one of the studies found, "brief exposure to body-positive Instagram posts resulted in improved body image and mood in young women, compared to idealized and appearance-neutral posts" (2019). Additionally, another study from Florida House Experience shows that: "both women and men compare theirbodies with those in the media" (2019). Especially the young generation tries to imitate models to be perfect like them. For example, according to the Pew Research Center"even as other platforms do not nearly match the overall reach of YouTube or Facebook, there are certain sites or apps, most notably Instagram, Snapchat and TikTok, that have an especially strong following among young adults. In fact, a majority of 18- to 29 -year-olds say they use Instagram $(71 \%)$ or Snapchat (65\%), while roughly half say the same for TikTok" (Auxier and Anderson, 2021). In short, all those studies show that social media has an essential influence on people. They support the cultural values and stereotypes of people. Nevertheless, some academicians suggest that advertisements try to change peoples' cultural values and ideas about stereotypes. Advertisements "portray women in less stereotypical roles" (Karlsson, 2015). For example, most famous companies use plus-size women, pregnant women, elderly instead of ideal body women or young women. Of course, it is still the same as in the past they use ideal body women or a young one, but at the same time, it is possible to see diversities as well (Hosen et al., 2020). Another example is related to racism. Nowadays, famous companies use both white and non-white models in their advertisements for their products to give the message that "race is no longer an issue" (Kahlor and Morris, 2014). Alternatively stated that as a result of the new advertising strategies, people do not only see white models. At the same time, they start to change their methods and cultural values to the new ones, which is we do not have any binary oppositions anymore about the colour of people. Moreover, most famous brand companies use different ethnic minorities in their advertisements, which is another way to reach more people. Such as "Asians, Blacks, and Hispanics identify most with ads that use Black actors, and Asians, Blacks, Hispanics, and Whites evaluate ads that use Black actors more positively than ads featuring White actors (Appiah, 2001b)" (Sierra et al.,2010). It implies by using different ethnic minorities advertisers aim to reach more people. All the studies expose that online social media has a considerable influence on people's lives. So, mar-keting companies effectively use social media to sell and introduce their products to consumers. Instagram is extensive social network, which is using by marketing companies and consumers. Correspondingly, social networks use social values, and ideologies start to reshape people. For example, some Instagram advertisements start to prepare advertisements against the ideal body image, stereotypes such as ideal body image, racism, and LGBT rights. In this 
technological century, advertisement is one of the powerful ways that reflect our ideologies, which is "a system of beliefs that determines how power relations are organised within a society" (Rayner et al., 2004). Any other way, advertising is powerful because it deals with values, attitudes and ideas to shape culture and people. Advertisers use language to persuade people to buy beliefs, values, and ideas besides commercial products. Especially nowadays, online brand companies give massive importance to online advertisement. They use verbal and visual language to communicate with people. The visual and verbal language that appears on online advertisements reveals the hidden meanings of stereotypes: body image, racism, and LGBT rights. In short, be-cause of online advertisement, famous fashion companies sell their ideologies and change the socio-cultural values of people. Therefore, in this analysis paper, the writer applies the Critical Discourse Analysis to reveal the hidden meanings of Tommy Hilfiger, H\&M, Calvin Klein's Instagram Advertisement Photos.

\section{Objectives of the Study}

The Objectives of the study are:

1) To apply the Fairclough, (1995) three-stage discourse analyses steps for analysing the verbal and visual language of advertisements.

2) To analyse the advertisements for identifying different types of discursive techniques used to change society's values and stereotypes.

\section{Research Questions}

This study examines/answers the following research questions:

a) What are verbal and visual that the advertisements use to influence and change people ideas about stereotypes (body image, racism, and LGBT rights)?

b) What are the hidden messages of the advertisements?

\section{Theoretical Framework}

According to Van Dijk (2015), Critical Discourse Analysis (CDA) "studies the way social-power abuse and inequality are enacted, reproduced, legitimated, and resisted by text and talk in the social and political context" (p.466). CDA wants to "understand, expose, and ultimately challenge social inequality" (Dijk, 2015). Discourse aims to control "the intentions, plans, knowledge, opinions, attitudes, and ideologies-as well as their consequent actions-of recipients" (Dijk, 2015). In short, according to Clark and Ivanic, (1997) CDA is related to identity, ideology, and gender as well. Nevertheless, CDA is "a material form of ideology, and language is invested by ideology" (Fairclough, 1995). Because of this, Fairclough established three-stage discourse analyses, which are description, interpretation, and explanation. The meanings of them are:

1) The object of analysis (including verbal, visual or verbal and visual texts).

2) The processes by means of which the object is produced and received (writing/ speaking/ designing and reading/listening/viewing) by human subjects.

3) The socio-historical conditions which govern these processes" (Janks, 2015).

In general, CDA is related to identity, ideology, and society. It is possible to suggest that for the advertising analysis, $\mathrm{CDA}$ is the appropriate method to realize the hidden meanings of advertisement photos to relate them with people's current cultural and social values. Consequently, "Language is merely a manifestation of a discourse, which in turn is a form of knowledge about society and culture and also about social events" (Ilyas and Afzal, 2021) that the paper studies verbal and visual language to analyse Instagram advertisements.

\section{MATERIALS AND METHODS:}

Qualitative analysis is used for this research. Three Online Instagram brand advertisements' photos are the secondary sources of this study. All the advertisements belong to famous fashion brand companies that use social media effectively. The randomly selected sample advertisements are:
a) Tommy Hilfiger (2 photos)
b) Calvin Kline ( 3 photos)
c) $\mathrm{H} \& \mathrm{M}(2$ photos)

\section{Data Collection}

For this study, data is collected from Instagram and download freely. The randomly selected sample is about famous brands of fashion companies. The photos are chosen according to the connection of the research questions, which are about stereotypes: ideal body image, racism, and LGBT rights.

\section{Data Analysis}

For the analysis, Fairclough's three-dimensional framework will be used, which are "(1) (description) text analysis; (2) (interpretation) processing analysis; 
(3) (explanation) social analysis" (Fairclough, 1995). This approach "enables you to focus on the signifiers that make up the text, the specific linguistic selections, their juxta positioning, their sequencing, their layout and so on" (Janks, 1997). In short, for verbal and visual analysis of the advertisements, CDA is the appropriate method to reveal the hidden meanings. Consequently, the following analysis part divides into three parts to apply the Fairclough threedimensional framework. Three-dimensions of discourse appear under each picture. Then, the analysis part continues with the discussion part.

\section{RESULTS AND DISCUSSION:}

\section{Analysis}

For the article, the writer uses 3 Instagram advertisement brands (Calvin Klein, Tommy Hilfiger, and $\mathrm{H} \& \mathrm{M})$ and seven photos from these famous brand advertisements; therefore, this part of the paper will analyse the advertisement photos by using Fairclough three-dimensional framework. The first two dimensions appear under each picture, and then for the last dimension, the hidden meanings of images will be revealed and discussed in the following part. All the photos took from social media, which is Instagram.

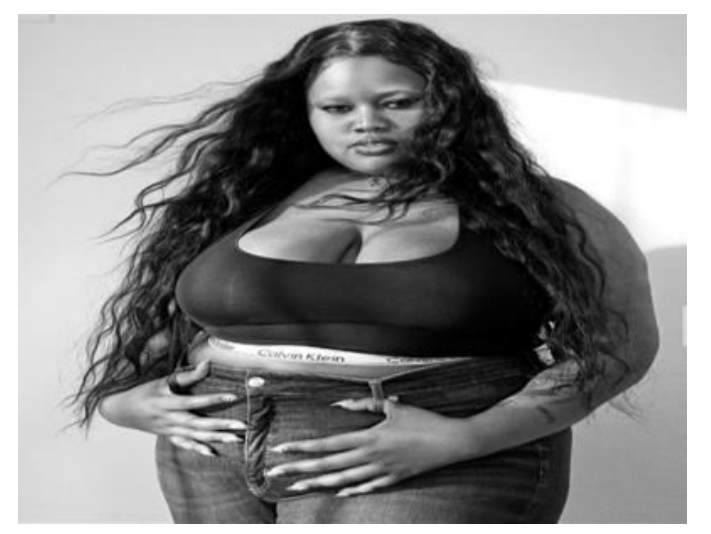

Fig 1: Calvin Klein.

\section{The original text that is under the picture}

Calvinklein "Just being Black, femme, plus-size is super important for me." Raisa Flowers. The moment, 2010. Discover the moment and shop the campaign. Link in bio. \#proudinmycalvins@ raisaflowers in the Modern Cotton plus Unlined Bralette (Karim et al., 2020). Documented by @ ryanmcginleystudios. Raisa

Interpretation or discourse practices:

\begin{tabular}{|c|c|}
\hline Strategies of the Advertisement & Linguistic Devices \\
\hline Using Celebrity & Kai Isaiah Jamal \\
\hline Colour & Black, White, and Pink \\
\hline
\end{tabular}

a photographer from New York City.

\section{Description or text analysis:}

Pronouns: Me (personal); Vocabulary (wording): Being Black, femme, plus-size; Persuasive Language: Super important; Tense: Past Simple.

\section{Interpretation or discourse practices}

\begin{tabular}{|c|c|}
\hline $\begin{array}{c}\text { Strategies of the } \\
\text { Advertisement }\end{array}$ & Linguistic Devices \\
\hline Using Celebrity & Raise Flowers \\
\hline Colour & $\begin{array}{c}\text { No colour - black and white } \\
\text { and she is looking to the consumers } \\
\text { with assertive/confident eyes and } \\
\text { posture. }\end{array}$ \\
\hline Pose and Gaze & $\begin{array}{r}\text { Rlogan } \\
\text { super important for me." }\end{array}$ \\
\hline Target audiences & Black and White, femme, plus-size \\
\hline
\end{tabular}

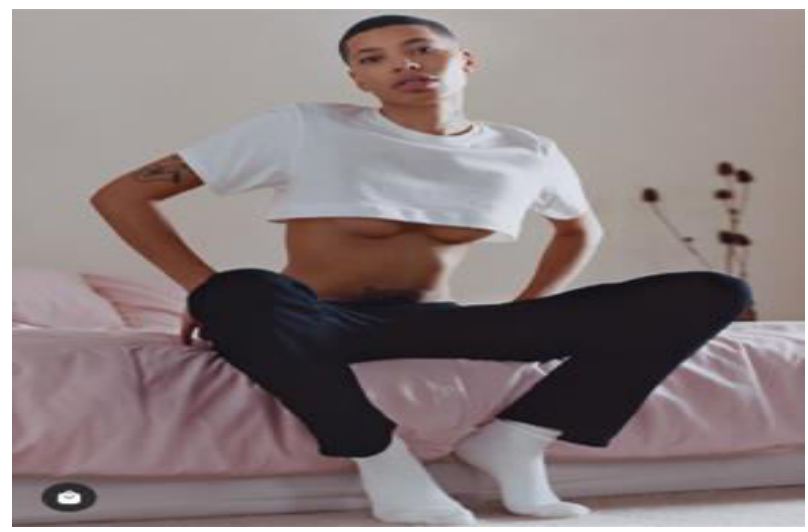

Fig 2: Calvin Klein.

The original text that is under the picture:

Kai Isaiah Jamal. The moment, 2020. "I'll never forget it. I call it my transition 2.0. Being able to step back into femininity and celebrate that glory...where once those thingswould have been really triggering. I felt weightless and free."Discover Moments of Pride. Shop the campaign. Link in bio. \#proudinmycalvins @kai_isaiah_jamaldocumented by@campbelladdy. Kai is a poet and activist from London. Campbell is a director and photographer from London.

\section{Description or text analysis:}

Pronouns: I (personal); Vocabulary (wording): transition, femininity; Persuasive Language: glory, weightless, free; Tense: Future, Simple Present, Past Simple, and Perfect Continuous Condition. 


\begin{tabular}{|c|c|}
\hline Pose and Gaze & $\begin{array}{r}\text { Kai Isaiah Jamal has a sexy posture on the pink bed. Also, Kai is glitzy and } \\
\text { looking to the consumers with assertive/confident eyes and posture. } \\
\text { "I'll never forget it. I call it my transition 2.0. Being able to step back into } \\
\text { femininity and celebrate that glory...where once those things would have been } \\
\text { really triggering. I felt weightless and free." }\end{array}$ \\
\hline Target audiences & $\begin{array}{c}\text { Trans, Black } \\
\text { Setting }\end{array}$ \\
\hline $\begin{array}{c}\text { Kia is wearing half short shirt that one can see Kai's half breasts. Kai has black } \\
\text { pants and white socks. Near the pink bed, it has a silhouette of a flower. }\end{array}$ \\
\hline
\end{tabular}

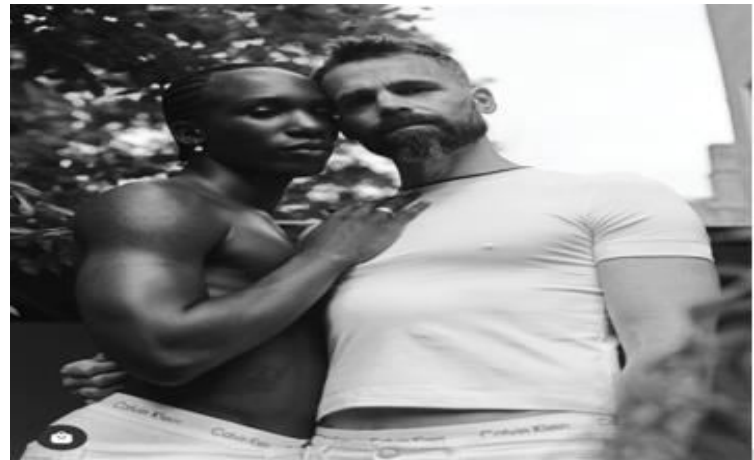

Fig 3: Calvin Klein.
The original text that is under the picture

"I knew it wouldn't be easy because we have an interracial relationship. But I knew.. It's very important to have someone who sees you for who you are and vice versa. Someone to unite with and to be one front." @christian_yav, @rolfdekort by@jeanpaulpaula \#PROUDINMYCALVINS.

\section{Description or text analysis:}

Pronouns: I, we, you (personal); Vocabulary (wording): interracial relationship; Persuasive Language: who sees you for who are, to be one front; Tense: Past Simple, Simple Present.

\section{Interpretation or discourse practices}

\begin{tabular}{|c|c|}
\hline Strategies of the Advertisement & Linguistic Devices \\
\hline Using Celebrity & Christian Yav and Rolf de Kort) \\
\hline Colour & Black and White \\
\hline Pose and Gaze & $\begin{array}{l}\text { They are attractive and passionate. They are looking to the consumers with } \\
\text { assertive/confident eyes and posture. }\end{array}$ \\
\hline Slogan & $\begin{array}{l}\text { "I knew it wouldn't be easy because we have an interracial relationship. But I } \\
\text { knew...It's very important to have someone who sees you for who you are and } \\
\text { vice versa. Someone to unite with and to be one front." }\end{array}$ \\
\hline Target audiences & White, Black, and Gay \\
\hline Setting & Black and white with blurred background \\
\hline
\end{tabular}

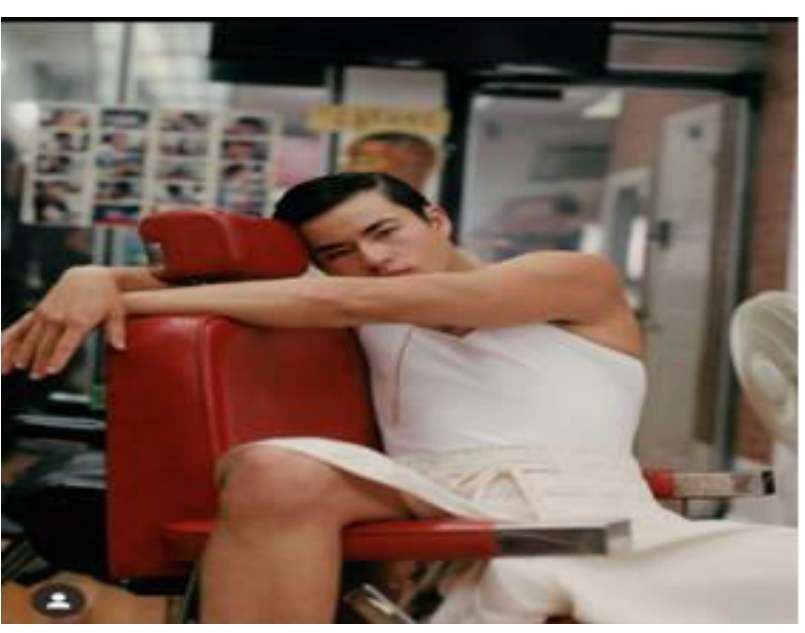

Fig 4: Tommy Hilfiger.

\section{The original text that is under the picture}

"By accepting our individualized experiences in this world, the fluidity of perspectives becomes.

\section{The original text that is under the picture}

"By accepting our individualized experiences in this world, the fluidity of perspectives becomes apparent. And remember, it is NEVER too late to become the person you have always imagined." @ chellaman \#TommyXIndya \#TommyHilfiger

\section{Description or text analysis}

Pronouns: Our, you (personal); Vocabulary (wording): Individualized, perspectives; Persuasive Language: NEVER too late; Tense: Simple Present Tense.

Interpretation or discourse practices

\begin{tabular}{|c|c|}
\hline Strategies of the Advertisement & Linguistic Devices \\
\hline Using Celebrity & Chella Man \\
\hline Colour & Black, Red, White, Silver, Gold, and Brown \\
\hline
\end{tabular}




\begin{tabular}{|c|c|}
\hline Pose and Gaze & $\begin{array}{c}\text { He is sitting at the red barber chair and looking at the customers. He has a } \\
\text { meaningful and mysterious glance. }\end{array}$ \\
\hline Slogan & $\begin{array}{r}\text { "By accepting our individualized experiences in this world, the fluidity of } \\
\text { perspectives becomes apparent. And remember, it is NEVER too late to become } \\
\text { the person you have always imagined." }\end{array}$ \\
\hline Target audiences & Trans, White, and Jewish-Asian \\
\hline Setting & Barbershop \\
\hline
\end{tabular}

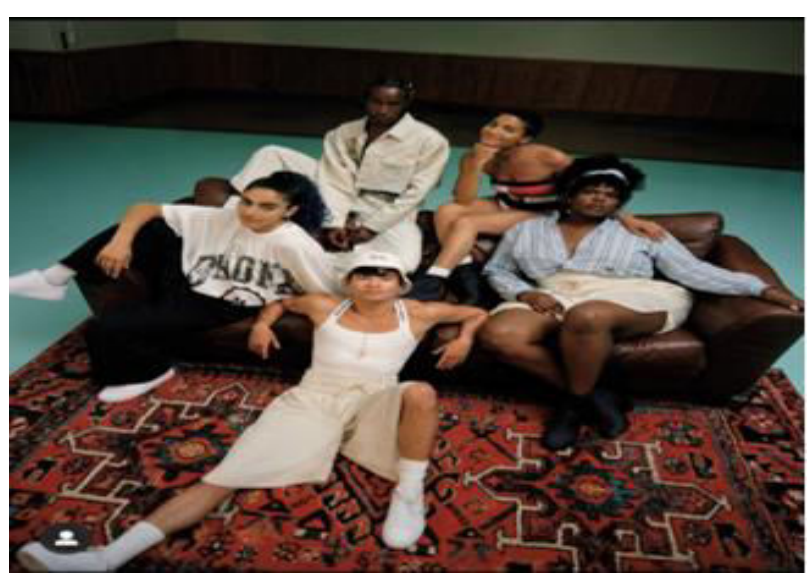

Fig 5: Tommy Hilfiger.

\section{The original text that is under the picture}

Style knows no boundaries - and neither should we. That's why we've teamed up with actor@ @Indya Moore to co-create a capsule of universal pieces designed without gender in mind. Excited? So are we! You can pre-order in the US today! Will be dropping in EU soon $:-$ \#TommyXIndya \#Tommy Hilfiger

\section{Description or text analysis}

Pronouns: We (personal); Vocabulary (Wording): styles, teamed up, capsule, universal pieces, mind, excited; Persuasive Language: no boundaries, without gender; Tense: Simple Present

\section{Interpretation or discourse practices}

\begin{tabular}{|c|c|}
\hline Strategies of the Advertisement & Linguistic Devices \\
\hline Using Celebrity & Cory Walkers, Indya Moore, Pidgeon Pagonis, Gia Love, Chella Man \\
\hline Colour & Black, Red, White, Green, Blue, \\
\hline Pose and Gaze & $\begin{array}{r}\text { Models sit down on the couch and the floor. Models are natural and looking to } \\
\text { the consumers (they are looking up) }\end{array}$ \\
\hline Slogan & $\begin{array}{c}\text { "Style knows no boundaries - and neither should we. That's why we've teamed } \\
\text { up with actor @IndyaMoore to co-create a capsule of universal pieces designed } \\
\text { without gender in mind. Excited? So are we!" }\end{array}$ \\
\hline Target audiences & All types of people \\
\hline Setting & Room \\
\hline
\end{tabular}

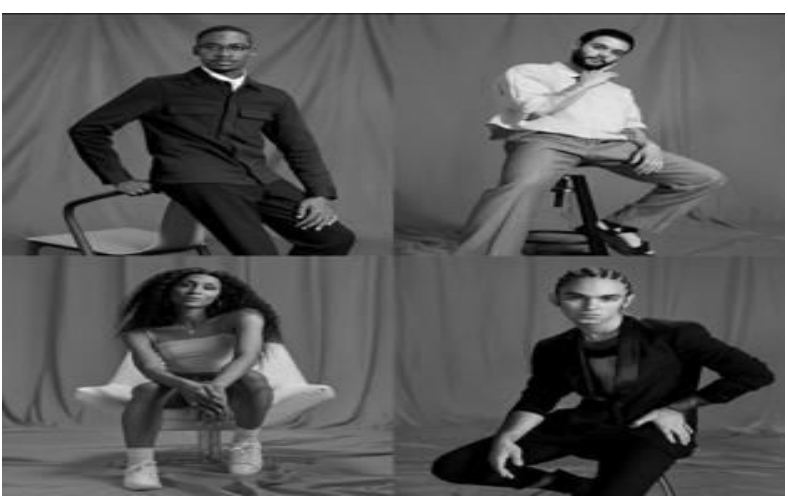

Fig 6: H\&M.

\section{The original text that is under the picture}

From the Stonewall riots to trans activists to \#L GBTIQ+ allies around the world, here's to all those who never stop fighting for \#Pride. Head to our stories to hear more. $\mathbb{P} \square \mathbb{P} \square$ \#HM \#Beyond the rain bow

\section{Description or text analysis}

Pronouns: All those (indefinite); Vocabulary (wording): stonewall Trans pride; Persuasive Language: never stop fighting; Tense: Simple Present.

Interpretation or discourse practices

\begin{tabular}{|c|c|}
\hline Strategies of the Advertisement & Linguistic Devices \\
\hline Using Celebrity & Lethabo Matseke, Francesco Cicconetti, Joaquin Nondoni, Michaela Jae \\
\hline Colour & Black and White \\
\hline Pose and Gaze & They are looking to the consumers. Sitting, Standing \\
\hline Slogan & $\begin{array}{r}\text { "From the Stonewall riots to trans activists to \#LGBTIQ+ allies around the } \\
\text { world, here's to all those who never stop fighting for \#Pride." }\end{array}$ \\
\hline
\end{tabular}




\begin{tabular}{|c|c|}
\hline Target audiences & All types of people \\
\hline Setting & Curtained place \\
\hline
\end{tabular}

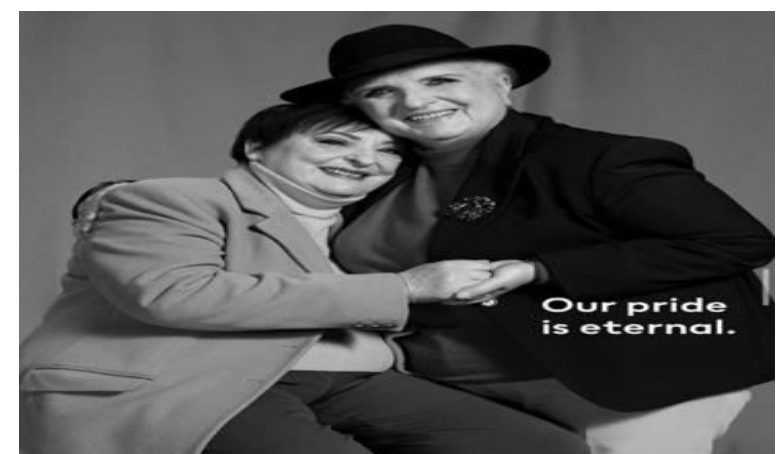

Fig 7: H\&M.

Interpretation or discourse practices

\begin{tabular}{|c|c|}
\hline Strategies of the Advertisement & Linguistic Devices \\
\hline Using Celebrity & Lidia \& Maria \\
\hline Colour & Black and White \\
\hline Pose and Gaze & $\begin{array}{l}\text { They are looking to the consumers. Sitting, Standing. They are hugging each other } \\
\text { and holding their hands with big and happy smiles on their face }\end{array}$ \\
\hline Slogan & $\begin{array}{c}\text { "Lidia \& Maria hid their sexuality for decades. Now, they share their love with the } \\
\text { world. }\end{array}$ \\
\hline Target audiences & World \\
\hline Setting & Grey background \\
\hline
\end{tabular}

\section{Explanation of the Photo Advertisements}

According to Fairclough, the third part of the Explanation is associated to social analysis, which is socio-cultural ideologies and discourse. It means that all the images show that advertisements are not only trying to influence people to sell their products. Correspondingly, it shows that they try to reach everyone without any boundaries. Besides, brand companies try to destroy or change our boundaries about stereotypes, which are beauty, racism, and LGBT people. Simply put, the images connote that they want equal rights for everyone and a world without prejudges. In short, those advertisements give messages to challenge the current discourses by establishing different discourses in society. For example, against the stereotypes, as one of the current researches emphasised "Advertisers change the attitude and opinions of people and create an idealized image of beauty to influence the viewers and sell their producers. Ideology of a beautiful and attractive woman is shaped through the social practice" (Azam et al., 2021).

However, they play with the beauty codes as well. They use plus-size, black, Trans, gay and lesbian, different ethnic minorities to reach them. Additionally, the slogans or the quotations signified that
The original text that is under the picture:

Lidia \& Maria hid their sexuality for decades. Now, they share their love with the world. $\$$ Check out our $\mathbb{P} \cap \square \square \square$ highlight for more. \#HM \#Beyond the rain bow \#Pride.

\section{Description or text analysis}

Pronouns: Our, Their (personal); Vocabulary (wording): sexuality decades, share their love; Persuasive Language: Our pride is eternal; Tense: Past Simple, Present Simple. they share their past, present, and future emotions, which is another way to influence people's cultural values about past difficulties, cur-rent situations, and future hopes (Akter et al., 2020). Those emotional reflections are the beginning of new cultural values and discourse for the future.

\section{RESULTS AND DISCUSSION:}

All the images show that advertisers use persuasive language to influence/change the ideas and beliefs of people. Still "advertisements create an idealized female image" (Azam et al., 2021), but some famous brands use their advertisements to change the discourses. For example, all the Instagram images show that it is possible to look at the binary opposition and stereotypes differently. Unfortunately, still, we have ideal body image, stereotypes about ideal body image, racism, and LGBT people.

However, most companies and governments try to change the rules and ideas about stereotypes in general. Consequently, it is possible to suggest that those verbal and visual images of the advertisements as a mentor for people to change their ideas. With these advertisement photos, maybe famous brand companies cannot reach the oldest people, but they can certainly reach Youngers and adults, which is a hope 
for equal rights for everyone. Consequently, those advertisements symbolise hope for the future without boundaries and stereotypes.

\section{CONCLUSION AND RECOMMENDATION:}

It is concluded that the selected advertisements use various linguistic and discursive techniques to attract and influence people. Their main aims are reach people, sell their product, and also create awareness about social and cultural issues. Advertisers use different people to represent that those brand companies think about everyone and want to reach everyone. The body type is not essential, and consumers can find different sizes of clothes. In addition, advertisers promote different body images to shape society's ideas to purchase their products and show like celebrities, who are confident, happy with their colour, body size, sexual orientation, and ethnic minorities. Even visual and verbal languages demonstrate that differences are beautiful and make you forget/remove your boundaries to be free.

I recommend that the future researcher compare the different countries advertisements to show the similarities and differences between stereotypes and gender differences.

\section{ACKNOWLEDGEMENT:}

The author wants to thank Prof. Tulin Bodamyal1, Vice Rector of Girne American University for her helpful suggestions and support.

\section{CONFLICT OF INTEREST:}

This study is my personal work, and so there is no conflict of interest to publish it.

\section{REFERENCES:}

1) Aazam et al. (2021). Female Representation in Advertisements: A Critical Discourse Analysis. International Review of Social Sciences, 9(6), p.33.

https://www.researchgate.net/publication/352561 $\underline{245}$

2) Akter et al. (2020). Influence of potential differential voltage on electric resistance of needle punched non-woven jute fabrics, Aust. J. Eng. Innov. Technol., 2(1), 1-6. https://doi.org/10.34104/ajeit.020.0106

3) Auxier B, and Anderson M. (2021). Social Media Use in 2021. Pew Research Center: Internet, Science \& Tech. APRIL 7, 2021. https://www.pewresearch.org/internet/2021/04/0 7/social-media-use-in-2021/
4) Berger J. (2008).Ways of seeing. [online]. British Broadcasting Corporation and Penguin Books. Available from:

http://waysofseeingwaysofseeing.com/ways-ofseeing-john-berger-5.7.pdf

5) Bullmore, J. (2021). What is advertising? [online] Advertising Association. Available from:

https://adassoc.org.uk/credos/what-isadvertising/

6) Chen J. (2020). Instagram ads vs Facebook ads: Which is better for your business? Sprout Social.

https://sproutsocial.com/insights/instagram-adsvs-facebook-ads/

7) Clark R, Ivanič R. (1997). Critical Discourse Analysis and Educational Change, pp. 217227. In Lier LV, Corson D (eds.), Encyclopedia of Language and Education, Springer.

8) Dijk, TAV. (2015). Critical Discourse Analysis, pp. 465-485. In Deborah Tannen, Heidi E. Hamilton, and Deborah Schiffrin (eds.), In the Handbook of Discourse Analysis, $2^{\text {nd }}$ Ed.John Wiley \& Sons, Inc. http://www.discourses.org/OldArticles/Critical\% 20Discourse\%20Analysis.pdf

9) Fairclough N. (1995). Critical Discourse Analysis: The Critical Study of Language, p.98. Longman, London and New York.

10) Hackley C. (2005). Advertising and Promotion. p.5. Sage Publications. London.

11) Helgeson VS. (2012). The Psychology of Gender, p.79. $4^{\text {th }}$ ed. Pearson.

12) Hosen F, Karim R, Islam R, Babu JH, Islam N, Hasan R, and Matin SMA. (2020). Monitoring of the time and action calendar of a T-shirt manufacturing, Aust. J. Eng. Innov. Technol., 2(6), 101-105. https://doi.org/10.34104/ajeit.020.01010105

13) Ilyas, M. and Afzal, N. (2021). Analyzing Jhumpa Lahiri's Narrative the Namesake: A Breakthrough beyond Text. Journal of Language and Linguistic Studies, 17(1). https://www.jlls.org/index.php/jlls/article/view/2 $\underline{483 / 805}$

14) Instagram.com, (2011). Tommy Hilfiger. https://www.instagram.com/tommyhilfiger/

15) Instagram.com, (2012). Calvin Klein. https://www.instagram.com/calvinklein/

16) Instagram.com, (2012). $H \& M$. https://www.instagram.com/hm/ 
17) Janks, H. (1997). Critical Discourse Analysis as a Research Tool. Discourse: Studies in the Cultural Politics of Education, 18(3), pp.329342.

https://www.uv.es/gimenez/Recursos/criticaldisc ourse.pdf

18) Jhally S. (1990). The Code of Advertising: Fetishism and the Political Economy of Meaning in the Consumer Society, Routledge, London.

19) Kahlor LA, Morris A. (2014). Whiteness Theory in Advertising: Racial Beliefs and Attitudes toward Ads. Howard Journal of Communications, 25(4), P. 415-430. https://doi.org/10.1080/10646175.2014.955929

20) Karim R, Razzak A, Mahabubuzzaman AKM, and Shahid A. (2019). Comparison of the quality parameter between cotton and melange process, Aust. J. Eng. Innov. Technol., 1(6), 21-30. https://doi.org/10.34104/ajeit.019.21030
21) Karlsson, S. (2015). Advertising as Discourse A study of print advertisements published in The New Yorker.

https://www.diva-portal.org/smash/get/diva2:8 40756/FULLTEXT01.pdf

22) King University, (2019). The link between social media and body image. King University Online. Available from: https://online.king.edu/news/social-media-andbody-image/

23) Rayner et al. (2004). As Media Studies: The Essential Introduction, Routledge, London.

24) Sierra JJ, Hyman MJ, Heiser RS. (2010). A Review of Ethnic Identity in Advertising. Wiley International Encyclopedia of Marketing, 4(1), p. 3.

https://doi.org/10.1002/9781444316568.wiem04 $\underline{032}$

Citation: Muhtaroğulları A. (2021). A critical discourse analysis for advertisements in Instagram: Calvin Klein, Tommy Hilfiger and H\&M, Br. J. Arts Humanit., 3(5), 140-148. https://doi.org/10.34104/bjah.02101400148 @ @ ( ) 